Original article / Оригинальная статья

DOI: https://doi.org/10.21285/2227-2925-2020-10-3-459-469

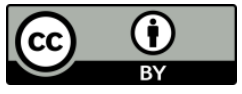

\title{
Impact of cultivation conditions on xylanase production and growth in Paenibacillus mucilaginosus
}

\author{
(C) Dung T. Ha*, Albert V. Kanarsky*, Zosia A. Kanarskaya*, \\ Andrei V. Shcherbakov ${ }^{\star *}$, Elena N. Shcherbakova**, Andrey V. Pranovich ${ }^{\star \star *}$ \\ *Kazan National Research Technological University, Kazan, Russian Federation \\ ${ }^{* *}$ All-Russia Research Institute for Agricultural Microbiology, St. Petersburg, Russian Federation \\ ${ }^{* * *}$ Abo Academy, Finland
}

\begin{abstract}
Xylanase is an enzyme that hydrolyses $\beta-1,4$ bonds in plant xylan. This enzyme is applied in the bioconversion of agro-industrial waste for xylooligosaccharide hydrolysate production to improve digestibility and nutrition value of animal feed, food processing, the utilisation and faster decomposition of crop debris in soil, as well as in cellulose bleaching and other industries. The current trend focuses on using renewable resources, such as agricultural waste, as substitutes for expensive purified xylan in producer screening and xylanase synthesis. This work aimed to determine the impact of Paenibacillus mucilaginosus cultivation conditions on the xylanase production yield. Rice bran ferment lysate along with birch and beech timber xylans were used as a carbon source. Temperature, medium $\mathrm{pH}, \mathrm{pH}$ correction factors, inoculant incubation time, carbon and nitrogen sources and concentrations were the studied criteria of xylanase biosynthesis and growth in bacteria P. ucilaginosus strain 560. We show that the xylanase biosynthesis and cultivation in $P$. mucilaginosus strain 560 are more practical and cost-effective with the use of a rice bran ferment lysatebased nutrient medium. Inductors contained in the rice bran ferment lysate improve the xylanase biosynthesis. Calcium ions also facilitate biosynthesis in the studied strain. Cultivation recommendations are: carbon source concentration in medium $0.5 \%$ of total reducing substances content; $0.2 \%$ carbamide as optimal nitrogen source; calcium hydroxide as an agent for medium $\mathrm{pH}$ correction to $6.0 \pm 0.2$; cultivation temperature $30 \pm 1{ }^{\circ} \mathrm{C}$. Under the specified conditions, cultivation of $P$. mucilaginosus does not require inoculate preprocessing, and a maximal xylanase activity in stationary culture reaches $20 \mathrm{U} / \mathrm{mL}$.
\end{abstract}

Keywords: rice bran, birch, beech, xylan, Paenibacillus mucilaginosus, culturing, xylanase

Information about the article: Received February 20, 2020; accepted for publication August 31, 2020; available online September 30, 2020.

For citation: Kha TZ, Kanarskiy AV, Kanarskaya ZA, Scherbakov AV, Scherbakova EN, Pranovich AV. Impact of cultivation conditions on xylanase production and growth in Paenibacillus mucilaginosus. Izvestiya Vuzov. Prikladnaya Khimiya $i$ Biotekhnologiya $=$ Proceedings of Universities. Applied Chemistry and Biotechnology. 2020;10(3):459-469. (In English) https://doi.org/10.21285/2227-2925-2020-10-3-459-469

удк 57.013:57.014

\section{Влияние условий культивирования на продуцирование ксиланазы и рост бактерий Paenibacillus mucilaginosus}

\author{
Т.3. Ха*, А.В. Канарский, 3.А. Канарская*, А.В. Щербаков*, \\ Е.Н. Щербакова* \\ *Казанский национальный исследовательский технологический университет (КНИТУ), \\ г. Казань, Российская Федерация \\ ** ВНИИ сельскохозяйственной микробиологии (ВНИИСХМ), \\ г. Санкт-Петербург, Российская Федерация, \\ *** Або Академия, Финляндия
}

Резюме: Ксиланаза - фермент, гидролизующий $\beta$-1,4-связи в ксиланах. Этот фрермент используется для получения из отходов агропромышленного комплекса гидролизата ксилоолигосахаридов с целью улучшения энергетической ценности и повышения усвояемости кормов для животных, обработки пищевых продуктов, утилизации и ускорения разложения поживных остатков в почве, а также в технологии отбелки целлюлозы и других областях. В настоящее время представляет интерес использование возобновляемых ресурсов, в частности, отходов сельскохозяйственного производства, в качестве субстрата вместо дорогого очищенного ксилана для скрининга продуцентов и выделения ксиланаз. Целью настоящей работы являлось определение влияния условий 
культивирования бактерий Paenibacillus mucilaginosus на продуцирование ксиланаз. В качестве источника углерода использовали ферментолизат рисовой шелухи, ксилан, выделенный из березы и бука. Изучено влияние температуры, рН среды, фракторов корректировки рН среды, продолжительности инкубации инокулята, источ-ников углерода и азота, и также их концентраций на биосинтез ксиланаз и рост итамма 560 P. mucilaginosus. Установлено, что для биосинтеза кисланазы культивирование итамма 560 P. mucilaginosus перспективно и экономически целесообразно проводить на питательной среде, приготовленной на основе фрерментолизата рисовой шелухи. Присутствующие в составе фрерментолизата рисовой шелухи индукторы улучшают биосинтез ксиланаз. Показано положительное влияние ионов кальция на биосинтез ксиланаз у рассматриваемого итамма. Рекомендуемые условия культивирования: концентрация источника уәлерода в питательной среде по общему количеству $P B$ - 0,5\%; в качестве источника азота целесообразно ис-

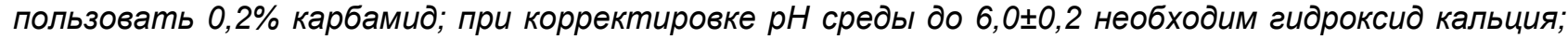
температура культивирования бактерий - $30 \pm 1{ }^{\circ} \mathrm{C}$. В указанных условиях культивирования P. mucilaginosus не требуется предварительного приготовления посевного материала, а максимальная активность синтезируемой ксиланазы в стационарной фазе роста бактерий достигает значения 20 ед./мл.

Ключевые слова: рисовая шелуха, береза, бук, ксилан, Paenibacillus mucilaginosus, культивирование, ксиланаза

Информация о статье: Дата поступления 20 февраля 2020 е.; дата принятия к печати 31 августа 2020 г.; дата онлайн-размещения 30 сентября 2020 г.

Для цитирования: Ха Т.З., Канарский А.В., Канарская З.А., Щербаков А.В., Щербакова Е.Н., Пранович A.В. Влияние условий культивирования на продуцирование ксиланазы и рост бактерий Paenibacillus mucilaginosus. Известия вузов. Прикладная химия и биотехнология. 2020. Т. 10. N 3. С. 459-469. https://doi.org/10.21285/2227-2925-2020-10-3-459-469

\section{INTRODUCTION}

The second most abundant renewable natural polysaccharide after cellulose, xylan is a major hemicellulose of grain and wood [1]. This complex polysaccharide consists of $\beta-1,4$-xylopyranosyl residues

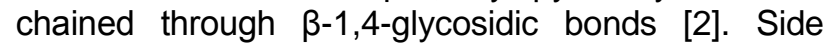
chains are linked to the backbone with $\beta-(1 \rightarrow 3)$ glycosidic bonds. Some hydroxyl groups in xylose residues can be acetylated and attached with 4-Omethyl-D-glucuronic acid and L-arabinofuranose [2, 3]. The xylan structure varies depending on the plant taxon and extraction method [4].

Xylan is abundant in hardwood (15-30\%) and conifer timber (7-10\%). A high xylan content (about $30 \%$ ) is found in straw, stems and other parts of annual plants and grasses (cereals, including sorghum, sugar cane cake, stems, cobs and husk of corn) [5]. Hardwood xylan is O-acetyl-4-O-methylglucuronoxylan. Conifer timber contains arabino-4-O-methylglucuronoxylan, which is distinguished from hardwood xylan by the absence of acetyl groups and presence of arabinofuranose branches. Grasses and annual plants usually possess arabinoxylans $[6,7]$. Linear unsubstituted xylan was also found in esparto grass [8], tobacco [9] and some sea algae [10] and contains xylopyranosyl residues linked by $1,3-\beta$ - and $1,4-\beta$-bonds $[10,11]$.

Xylans are the main antinutrient components of plant material that hamper nutrient absorption in the gastrointestinal tract of monogastric animals. $\mathrm{Xy}$ lan is hydrolysed by xylanases (1,4- $\beta$-D-xylanases, EC 3.2.1.8) used for xylooligosaccharide (XOS) hydrolysate production from agricultural waste to improve digestibility and nutritive value of animal feed, in food processing, in the utilisation and effective decomposition of crop debris in soil, as well as in cellulose bleaching and other industries [12]. Xylanases are the main endoenzymes hydrolysing $\beta-1,4$-bonds in xylan, the major hemicellulose polymer [13]. The current trend focuses on the use of renewable resources, such as agricultural waste, as substitutes for expensive purified xylan in producer screening and xylanase synthesis [14]. Fungi are known promising producers of xylanases. However, today's biotechnology opts for bacteria as primary xylanase producers, which are distinguished from mycelial fungi by a higher growth rate and effective production and absorption of carbon from various types of plant matter. Bacteria can also produce xylanase in large volumes and at moderate enzyme purification costs[15].

Paenibacillus bacteria are able to hydrolyse various carbohydrates and produce numerous extracellular enzymes, including xylanase. This xylandegrading genus includes the species of $P$. favisporus, P. phyllosphaerae, P. barcinonensis and P. panacisoli [16-19]. Besides the benefits of their enzymatic action, the biomass and other products of Paenibacillus metabolism can supplement feed additives to replenish the diet of farm animals and birds with biologically active substances [20]. Sustainable growth in animal and poultry farming demands for the development of high-quality compound feeds containing enzyme additives. The Russian market is dominated by import fodder enzyme preparations, whereas their domestic production is very limited. The search for new efficient xylanase producer strains in the animal feed industry and the development of scalable fermentation technologies 
for the substitution of imported fermented fodder preparations is a pressing issue.

The present work aimed to determine the impact of Paenibacillus mucilaginosus cultivation conditions on the xylanase production yield.

\section{EXPERIMENTAL}

Xylanase producer. Strain 560 of bacterium $P$. mucilaginosus was provided by the Russian Collection of Agricultural Microorganisms (RCAM, AllRussian Research Institute for Agricultural Microbiology, St. Petersburg).

Nutrient growth media. Submerged cultivation of $P$. mucilaginosus was carried out on the Alexandrov's nutrient medium modified as follows, $\%: \mathrm{NaCl}-0.02$, $\mathrm{K}_{2} \mathrm{HPO}_{4}-0.2, \mathrm{MgSO}_{4} .7 \mathrm{H}_{2} \mathrm{O}-0.05, \mathrm{CaCO}_{3}-0.01$, $\left(\mathrm{NH}_{4}\right)_{2} \mathrm{SO}_{4}-0.1$, yeast extract -0.1 [21].

Rice bran fibre ferment hydrolysate containing $0.5 \%$ of the total reducing substances (RS) content was used as a carbon source. The bran was pretreated with $2.5 \%$ sodium hydroxide, with a solidsurface to sodium hydroxide saline ratio of $1: 8$, treatment temperature was $120 \pm 1{ }^{\circ} \mathrm{C}$ and treatment time $20 \mathrm{~min}$. The fibre was then rinsed with tap water and exposed for $24 \mathrm{~h}$ to the Accellerase 1500 enzyme complex containing exoglucanase, endoglucanase, hemicellulase and beta-glucosidase at $55 \pm 1{ }^{\circ} \mathrm{C}, \mathrm{pH}$ $5.5 \pm 0.3$. This ferment lysate contained RS available for bacterial growth. Silicon-containing lye segregated from fibre was used as a medium $\mathrm{pH}$ correction factor.
Birchwood xylan was also used as a carbon source [22]. Xylan was extracted from birchwood chips (Betula pendula) through oxygen-free steaming at $150-155^{\circ} \mathrm{C}$ and $0.60-0.65 \mathrm{MPa}$ excess pressure. Xylan was precipitated from the resulting water extract by intensive vortexing in an ethanol/water solution $(85: 15)$ with overnight exposure for complete coagulation. After decantation, xylan precipitate was vacuum sieved with a filter paper (Black ribbon). Eluted xylan was vacuum dried at $40^{\circ} \mathrm{C}$ for $48 \mathrm{~h}$.

Beechwood xylan (Cath Roth) was used as a carbon source in comparison assays.

Nutrient medium was autoclaved at $120{ }^{\circ} \mathrm{C}$ and $1 \mathrm{~atm}$. Sterile medium was corrected to neutral $\mathrm{pH}$ with calcium hydroxide. Cultivation was carried out with $250 \mathrm{~mL}$ Erlenmeyer flasks in $100 \mathrm{~mL}$ medium stirred continuously at $200 \mathrm{rpm}$ on an ES-20 incubator shaker for 3 days at $30^{\circ} \mathrm{C}$. The flasks were inoculated at $5 \%$ relative to medium volume.

Experiments were designed as OFAT (OneFactor-At-a-Time). The OFAT approach was used to study the influence of cultivation conditions (substrate concentration, medium $\mathrm{pH}$, temperature, inoculant incubation time, nitrogen source, nitrogen source concentration, carbon source) on the growth and metabolic yield in $P$. mucilaginosus bacteria. The method varies one tested factor per trial, while leaving the others constant [23]. The OFAT experimental design is detailed in Table 1.

Table 1. Experimental design

Таблица 1. Планирование эксперимента

\begin{tabular}{|c|c|c|c|c|c|c|c|}
\hline $\begin{array}{l}\text { Expe- } \\
\text { riment } \\
\text { number }\end{array}$ & $\begin{array}{c}\text { Substrate } \\
\text { concentration, } \\
\%\end{array}$ & $\begin{array}{l}\text { Temperature, } \\
{ }^{\circ} \mathrm{C}\end{array}$ & $\begin{array}{c}\mathrm{pH} \\
\text { corrector }\end{array}$ & $\mathrm{pH}$ & Carbon source & $\begin{array}{l}\text { Inoculate } \\
\text { Incubation } \\
\text { time, } \mathrm{h}\end{array}$ & $\begin{array}{l}\text { Nitrogen source } \\
\text { and } \\
\text { concentration } \\
\end{array}$ \\
\hline 1 & $\begin{array}{c}0.25 ; 0.5 \\
0.75 ; 1\end{array}$ & 30 & $\begin{array}{l}\text { Calcium } \\
\text { hydroxide }\end{array}$ & 7 & $\begin{array}{c}\text { Rice bran } \\
\text { ferment lysate }\end{array}$ & 24 & $\begin{array}{c}0.1 \%\left(\mathrm{NH}_{4}\right)_{2} \mathrm{SO}_{4} \\
+0.1 \% \text { yeast } \\
\text { extract }\end{array}$ \\
\hline 2 & $\begin{array}{l}\text { Opt. value } \\
\text { as in Trial } 1\end{array}$ & $25,30,35$ & $\begin{array}{l}\text { Calcium } \\
\text { hydroxide }\end{array}$ & 7 & $\begin{array}{c}\text { Rice bran } \\
\text { ferment lysate }\end{array}$ & 24 & $\begin{array}{c}0.1 \%\left(\mathrm{NH}_{4}\right)_{2} \mathrm{SO}_{4}+ \\
0.1 \% \text { yeast } \\
\text { extract }\end{array}$ \\
\hline 3 & $\begin{array}{l}\text { Opt. value } \\
\text { as in Trial } 1\end{array}$ & $\begin{array}{l}\text { Opt. value } \\
\text { as in Trial } 2\end{array}$ & $\begin{array}{c}\text { Calcium } \\
\text { hydroxide, } \\
\text { sodium } \\
\text { hydroxide, } \\
\text { Si- } \\
\text { containing } \\
\text { lye }\end{array}$ & 7 & $\begin{array}{c}\text { Rice bran } \\
\text { ferment lysate }\end{array}$ & 24 & $\begin{array}{c}0.1 \%\left(\mathrm{NH}_{4}\right)_{2} \mathrm{SO}_{4}+ \\
0.1 \% \text { yeast } \\
\text { extract }\end{array}$ \\
\hline 4 & $\begin{array}{l}\text { Opt. value } \\
\text { as in Trial } 1\end{array}$ & $\begin{array}{l}\text { Opt. value } \\
\text { as in Trial } 2\end{array}$ & $\begin{array}{l}\text { Opt. value } \\
\text { as in Trial } 3\end{array}$ & $\begin{array}{l}6,7 \\
8,9\end{array}$ & $\begin{array}{c}\text { Rice bran } \\
\text { ferment lysate }\end{array}$ & 24 & $\begin{array}{c}0.1 \%\left(\mathrm{NH}_{4}\right)_{2} \mathrm{SO}_{4}+ \\
0.1 \% \text { yeast } \\
\text { extract }\end{array}$ \\
\hline 5 & $\begin{array}{l}\text { Opt. value } \\
\text { as in Trial } 1\end{array}$ & $\begin{array}{l}\text { Opt. value } \\
\text { as in Trial } 2\end{array}$ & $\begin{array}{l}\text { Opt. value } \\
\text { as in Trial } 3\end{array}$ & $\begin{array}{c}\text { Opt. } \\
\text { value as } \\
\text { in Trial } 4\end{array}$ & $\begin{array}{c}\text { Rice bran } \\
\text { ferment lysate, } \\
\text { birch xylan, beech } \\
\text { xylan }\end{array}$ & 24 & $\begin{array}{c}0.1 \%\left(\mathrm{NH}_{4}\right)_{2} \mathrm{SO}_{4}+ \\
0.1 \% \text { yeast } \\
\text { extract }\end{array}$ \\
\hline 6 & $\begin{array}{l}\text { Opt. value } \\
\text { as in Trial } 1\end{array}$ & $\begin{array}{l}\text { Opt. value } \\
\text { as in Trial } 2\end{array}$ & $\begin{array}{l}\text { Opt. value } \\
\text { as in Trial } 3\end{array}$ & $\begin{array}{c}\text { Opt. } \\
\text { value as } \\
\text { in Trial } 4 \\
\end{array}$ & $\begin{array}{l}\text { Opt. value } \\
\text { as in Trial } 5\end{array}$ & $\begin{array}{c}0,12,24 \\
36,48\end{array}$ & $\begin{array}{c}0.1 \%\left(\mathrm{NH}_{4}\right)_{2} \mathrm{SO}_{4}+ \\
0.1 \% \text { yeast ex- } \\
\text { tract } \\
\end{array}$ \\
\hline 7 & $\begin{array}{l}\text { Opt. value } \\
\text { as in Trial } 1\end{array}$ & $\begin{array}{l}\text { Opt. value } \\
\text { as in Trial } 2\end{array}$ & $\begin{array}{l}\text { Opt. value } \\
\text { as in Trial } 3\end{array}$ & $\begin{array}{l}\text { Opt. value } \\
\text { as in Trial } \\
4\end{array}$ & $\begin{array}{l}\text { Opt. value } \\
\text { as in Trial } 5\end{array}$ & $\begin{array}{l}\text { Opt. value } \\
\text { as in Trial } 6\end{array}$ & $\begin{array}{c}\text { Total } \\
\text { concentration } \\
0.2 \% \\
\end{array}$ \\
\hline 8 & $\begin{array}{l}\text { Opt. value } \\
\text { as in Trial } 1\end{array}$ & $\begin{array}{l}\text { Opt. value } \\
\text { as in Trial } 2\end{array}$ & $\begin{array}{l}\text { Opt. value } \\
\text { as in Trial } 3\end{array}$ & $\begin{array}{l}\text { Opt. value } \\
\text { as in Trial } \\
\quad 4\end{array}$ & $\begin{array}{l}\text { Opt. value } \\
\text { as in Trial } 5\end{array}$ & $\begin{array}{l}\text { Opt. value } \\
\text { as in Trial } 6\end{array}$ & $\begin{array}{c}0 ; 0.02 ; 0.1 ; 0.2 ; \\
0.3 ; 0.4 \% \\
\text { of opt. nitrogen } \\
\text { source in Trial } 7\end{array}$ \\
\hline
\end{tabular}


Trial 1 assessed the xylanase activity and growth parameters of $P$. mucilaginosus strain 560 under rice bran ferment lysate concentrations varying from 0.25 to $1 \%$ total $\mathrm{RS}$. Temperature, $\mathrm{pH}$, inoculate incubation time, nitrogen sources and consumption rate were set constant. The RS concentration in ferment lysate corresponding to the maximal xylanase activity and optimal growth parameters in Trial 1 was fixed downstream in Trial 2, which tested the effect of temperature on bacterial growth and xylanase yield under other fixed parameters $(\mathrm{pH}$, incubation time, nitrogen source and consumption rate). Trials 3-8 are designed likewise by varying one cultivation parameter at a time.

Assessment of growth parameters. Specific growth rate, bacterial biomass generation time and total yield were estimated as recommended in [24]. Biomass was pelleted by centrifugation with a 5418 $\mathrm{R}$ Eppendorf microcentrifuge at $12,000 \mathrm{rpm}$ for 10 min. Biomass yield was determined thermogravimetrically with an MX-50 moisture analyser.

Assessment of xylanase activity. The xylanase activity and residual RS content of undegraded carbohydrates in supernatant after a 12, 24, 48 and 72-h submerged cultivation of $P$. mucilaginosus were measured by adding concentrated sulfuric acid in the ratio 1:1. Enzymatic activity was measured as in [25], with certain modifications. Xylanase activity was assessed with a $1 \%$ beechwood xylan substrate $(1 \mathrm{~g}$ of xylan per $100 \mathrm{~mL}$ of acetate buffer, pH 6). Enzymatic activity was measured relative to the RS value [26]. The measurement procedure was as follows: $0.12 \mathrm{~mL}$ of supernatant with $1.2 \mathrm{~mL}$ of substrate were incubated for $1 \mathrm{~h}$ at $50{ }^{\circ} \mathrm{C}$ followed by the addition of $0.6 \mathrm{~mL}$ of 3,5-dinitrosalicylic acid (DNS reagent). In the control, $1.2 \mathrm{~mL}$ of substrate was mixed with $0.6 \mathrm{~mL}$ of DNS reagent and $0.12 \mathrm{~mL}$ of supernatant. Tubes with the substrate, culture medium and DNS reagent were boiled in a water bath for $10 \mathrm{~min}$, cooled down and $6 \mathrm{~mL}$ of distilled water was added before optical density measurement at $540 \mathrm{~nm}$. One xylanase activity unit was defined as the amount of enzyme needed to hydrolyse $1 \mathrm{~g}$ of substrate $(30 \%$ of reaction total) to monosugars in $1 \mathrm{~h}$ under assumed $\mathrm{pH}$ and temperature.

Trials were in the form of biological and analytical assays performed in triplicate, and statistical analyses were performed using the MS Excel 2010 and Prism 7 software.

\section{DISCUSSION}

Effect of substrate concentration on growth and xylanase biosynthesis. Cost-efficient and therefore practical sources of carbon are substrates derived from recycled plant matter, such as crop debris and timber stands. Grain husk, straw, bran and wood shavings are typically rich in xylans.

Our trials demonstrate an impact of the substrate concentration, such as rice bran ferment lysate, on the growth and secreted xylanase activity in $P$. mucilaginosus strain 560 . Higher substrate con- centrations corresponded to a higher enzyme activity (Fig. 1, a), lower generation time and increased specific growth rate in bacteria (Table 2). Maximal xylanase activity reached $7.66 \mathrm{U} / \mathrm{mL}$ after $24 \mathrm{~h}$ of cultivation, with the total rice bran ferment lysate RS value of $0.5 \%$, effective growth conditions and maximal biomass yield of $40 \%$.

Effect of cultivation temperature. In $0.5 \%$ ferment lysate medium trials, a cultivation temperature of $30 \pm 1{ }^{\circ} \mathrm{C}$ facilitated both effective xylanase production and optimal bacterial growth (Fig. 1,b). A higher temperature of $35{ }^{\circ} \mathrm{C}$ was associated with a higher specific growth rate and 2-fold reduced generation time compared to culturing at $25{ }^{\circ} \mathrm{C}$, and 1.5 -fold reduction compared with $30{ }^{\circ} \mathrm{C}$. However, the biomass yield at 25 or $35^{\circ} \mathrm{C}$ diminished compared with culturing at $30^{\circ} \mathrm{C}$ (see Table 2).

The effect of medium $\mathrm{pH}$. Xylanase activity and growth in $P$. mucilaginosus was significantly influenced by the nutrient medium $\mathrm{pH}$ (Fig. 2) and $\mathrm{pH}$ correction factors. Table 2 shows that noncrystalline silicon-containing lye as a $\mathrm{pH}$ corrector facilitates bacterial growth and increases the specific growth rate. However, the use of silicon-containing lye or sodium hydroxide correctors was associated with a lower xylanase activity and reduced biomass yield (Fig. 2, a; see Table 2).

A maximal yield was observed with calcium hydroxide (see Table 2), which is likely explained by the regulatory role calcium ions play in many cellular processes. Calcium is a known stabilising factor in the outer lipopolysaccharide membrane and cellular wall in Gram-negative bacteria [27] and a stimulator of bacterial protein biosynthesis resulting in higher biomass yield and enzyme activity [28]. A maximal xylanase activity of $11 \mathrm{U} / \mathrm{mL}$ was observed after a $48 \mathrm{~h}$ cultivation of $P$. mucilaginosus on a calcium hydroxide-corrected medium (see Fig. 2, a), which may be related to the calcium-mediated stabilisation and regulation of the enzyme activity [29-31].

The calcium hydroxide adjustment of the medium's $\mathrm{pH}$ from 6 to 9 resulted in the arrest of bacterial growth at $\mathrm{pH} 9$. Adding calcium hydroxide for $\mathrm{pH}$ adjustment of 6 to 8 accelerated the specific growth rate and had a 2 -fold reduction on generation time ( $6 \mathrm{~h}$ at $\mathrm{pH} 6$ vs. $3 \mathrm{~h}$ at $\mathrm{pH} 8$, see Table 2).

This result conforms with another study [32], where the growth of rhizobacteria is shown to be coaffected by $\mathrm{pH}$ and calcium ion concentrations. In our trials, a maximal biomass yield of $38 \%$ is observed at a neutral medium pH of 7.0 (see Table 2). The maximal xylanase activity reaches $15 \mathrm{U} / \mathrm{mL}$ under $\mathrm{pH} 6.0$ following a $48 \mathrm{~h}$ cultivation on a rice bran ferment lysate medium (Fig. 2, b).

Effect of carbon source. Cultivation trials with various carbon sources demonstrated a peak biomass accumulation (about 60\%) with beechwood xylan (see Table 2).

Rice bran ferment lysate was identified as the most effective source of carbon for xylanase produc- 
Kha T.Z., Kanarskiy A.V., Kanarskaya Z.A. et al. Impact of cultivation conditions ...

Ха Т.3., Канарский А.В., Канарская 3.А. и др. Влияние условий культивирования ..

Table 2. Effect of cultivation conditions on growth kinetics

in P. mucilaginosus strain 560

Таблица 2. Влияние условий культивирования на кинетические параметры роста штамма 560 бактерий P. mucilaginosus

\begin{tabular}{|c|c|c|c|c|}
\hline Parameter & Range & $\begin{array}{l}\text { Specific growth rate, } \\
\mathrm{h}^{-1}\end{array}$ & Generation time, $\mathrm{h}$ & Biomass yield, \% \\
\hline $\begin{array}{c}\text { Substrate } \\
\text { concentration, \% }\end{array}$ & $\begin{array}{c}0.25 \\
0.5 \\
0.75 \\
1\end{array}$ & $\begin{array}{l}0.17 \pm 0.05 \\
0.22 \pm 0.03 \\
0.26 \pm 0.05 \\
0.23 \pm 0.05\end{array}$ & $\begin{array}{l}4.10 \pm 0.59 \\
3.09 \pm 0.41 \\
2.71 \pm 0.25 \\
2.96 \pm 0.30\end{array}$ & $\begin{array}{l}37.68 \pm 2.62 \\
40.11 \pm 2.83 \\
32.09 \pm 2.65 \\
33.13 \pm 2.63\end{array}$ \\
\hline Temperature, ${ }^{\circ} \mathrm{C}$ & $\begin{array}{l}25 \\
30 \\
35\end{array}$ & $\begin{array}{l}0.11 \pm 0.04 \\
0.15 \pm 0.03 \\
0.24 \pm 0.03\end{array}$ & $\begin{array}{l}6.45 \pm 0.66 \\
4.54 \pm 0.48 \\
2.86 \pm 0.14\end{array}$ & $\begin{array}{l}18.26 \pm 1.52 \\
38.48 \pm 2.72 \\
26.55 \pm 3.02\end{array}$ \\
\hline $\mathrm{pH}$ correction factor & $\begin{array}{l}\text { Calcium hydroxide } \\
\text { Sodium hydroxide } \\
\text { Si-containing lye }\end{array}$ & $\begin{array}{l}0.21 \pm 0.02 \\
0.31 \pm 0.04 \\
0.45 \pm 0.04\end{array}$ & $\begin{array}{l}3.29 \pm 0.27 \\
2.25 \pm 0.27 \\
1.54 \pm 0.12\end{array}$ & $\begin{array}{l}29.23 \pm 2.69 \\
18.92 \pm 1.45 \\
17.20 \pm 1.65\end{array}$ \\
\hline $\mathrm{pH}$ & $\begin{array}{l}6 \\
7 \\
8\end{array}$ & $\begin{array}{l}0.11 \pm 0.01 \\
0.15 \pm 0.03 \\
0.20 \pm 0.05\end{array}$ & $\begin{array}{l}6.89 \pm 0.57 \\
4.54 \pm 0.18 \\
3.52 \pm 0.10\end{array}$ & $\begin{array}{l}19.24 \pm 2.02 \\
38.48 \pm 2.67 \\
19.91 \pm 1.82\end{array}$ \\
\hline Carbon source & $\begin{array}{c}\text { Birchwood xylan } \\
\text { Beechwood xylan } \\
\text { Rice bran ferment } \\
\text { lysate }\end{array}$ & $\begin{array}{l}0.16 \pm 0.02 \\
0.20 \pm 0.03 \\
0.21 \pm 0.02\end{array}$ & $\begin{array}{l}4.24 \pm 0.55 \\
3.48 \pm 0.25 \\
3.29 \pm 0.27\end{array}$ & $\begin{array}{l}44.57 \pm 2.85 \\
59.43 \pm 3.02 \\
39.23 \pm 2.12\end{array}$ \\
\hline $\begin{array}{l}\text { Inoculate incubation } \\
\text { time, } \mathrm{h}\end{array}$ & $\begin{array}{c}0 \\
12 \\
24 \\
36 \\
48\end{array}$ & $\begin{array}{l}0.16 \pm 0.03 \\
0.15 \pm 0.03 \\
0.09 \pm 0.01 \\
0.10 \pm 0.01 \\
0.13 \pm 0.02\end{array}$ & $\begin{array}{l}4.36 \pm 0.12 \\
4.57 \pm 0.15 \\
7.47 \pm 0.81 \\
6.77 \pm 0.70 \\
5.55 \pm 0.71\end{array}$ & $\begin{array}{l}43.30 \pm 2.63 \\
34.43 \pm 2.70 \\
21.38 \pm 2.22 \\
33.75 \pm 2.68 \\
56.16 \pm 3.08\end{array}$ \\
\hline Nitrogen source & $\begin{array}{c}\text { No nitrogen } \\
\mathrm{NH}_{4} \mathrm{NO}_{3} \\
\left(\mathrm{NH}_{4}\right)_{2} \mathrm{SO}_{4} \\
\text { Yeast extract } \\
\left(\mathrm{NH}_{4}\right)_{2} \mathrm{SO}_{4}+\text { yeast } \\
\text { extract } \\
\text { Corn extract } \\
\text { Pepton } \\
\text { Carbamide } \\
\text { Betafin }\end{array}$ & $\begin{array}{l}0.12 \pm 0.01 \\
0.19 \pm 0.02 \\
0.19 \pm 0.02 \\
0.11 \pm 0.01 \\
0.15 \pm 0.01 \\
\\
0.06 \pm 0.01 \\
0.15 \pm 0.01 \\
0.17 \pm 0.03 \\
0.23 \pm 0.05\end{array}$ & $\begin{array}{c}5.84 \pm 0.61 \\
3.72 \pm 0.22 \\
3.63 \pm 0.20 \\
6.68 \pm 0.25 \\
4.67 \pm 0.53 \\
\\
12.17 \pm 0.74 \\
4.68 \pm 0.46 \\
4.08 \pm 0.46 \\
3.00 \pm 0.47\end{array}$ & $\begin{array}{l}16.68 \pm 1.82 \\
22.40 \pm 2.12 \\
25.57 \pm 2.07 \\
33.16 \pm 2.82 \\
37.10 \pm 2.68 \\
\\
49.31 \pm 2.64 \\
29.87 \pm 2.12 \\
15.29 \pm 1.92 \\
11.39 \pm 1.22\end{array}$ \\
\hline Carbamide content, \% & $\begin{array}{c}0.02 \\
0.1 \\
0.2 \\
0.3\end{array}$ & $\begin{array}{l}0.21 \pm 0.04 \\
0.16 \pm 0.01 \\
0.15 \pm 0.01 \\
0.08 \pm 0.01\end{array}$ & $\begin{array}{l}3.25 \pm 0.36 \\
4.33 \pm 0.45 \\
4.51 \pm 0.35 \\
8.84 \pm 0.70\end{array}$ & $\begin{array}{l}29.18 \pm 2.27 \\
18.88 \pm 1.62 \\
15.21 \pm 1.65 \\
10.44 \pm 1.60\end{array}$ \\
\hline
\end{tabular}

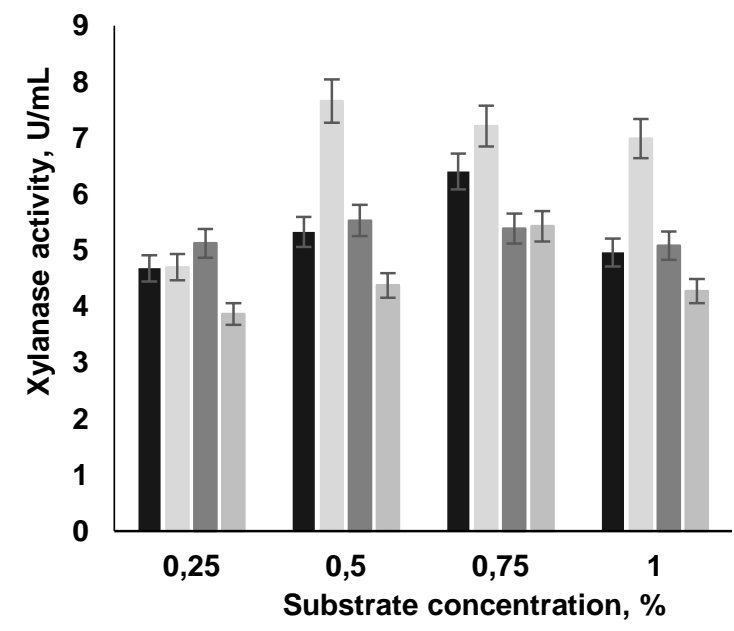

a

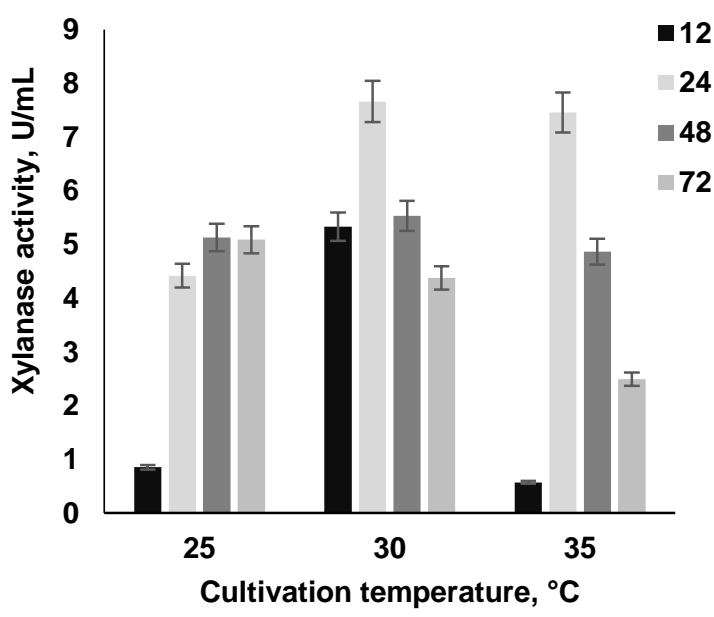

b

Fig. 1. Effect of rice bran ferment lysate carbohydrate concentration (a) and cultivation temperature (b) on xylanase activity $(\mathrm{U} / \mathrm{mL})$ in P. mucilaginosus strain 560

Рис. 1. Влияние концентрации углеводов в ферментолизате рисовой шелухи (a) и температуры культивирования (b) на ксиланазную активность (ед./мл) штамма 560 P. mucilaginosus 
Kha T.Z., Kanarskiy A.V., Kanarskaya Z.A. et al. Impact of cultivation conditions ...

Ха Т.3., Канарский А.В., Канарская 3.А. и др. Влияние условий культивирования ...

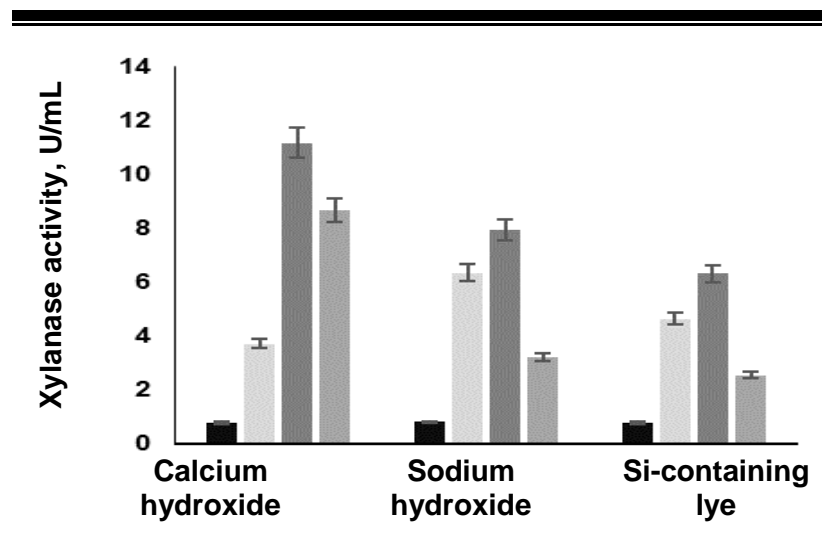

a

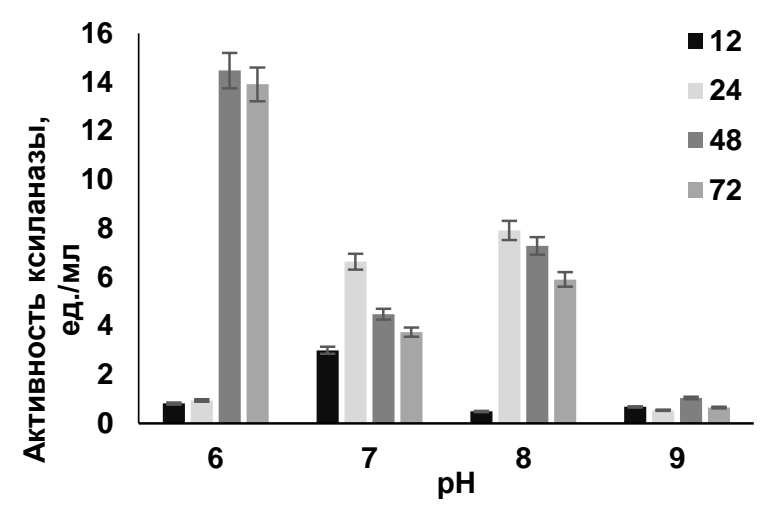

b

Fig. 2. Effect of pH correction factors (a) and acidity (b) on xylanase activity (U/mL) in $P$. mucilaginosus strain 560

Рис. 2. Влияние факторов корректировки рН среды (а) и кислотности среды (b) на ксиланазную активность (ед./мл) штамма 560 бактерий $P$. mucilaginosus

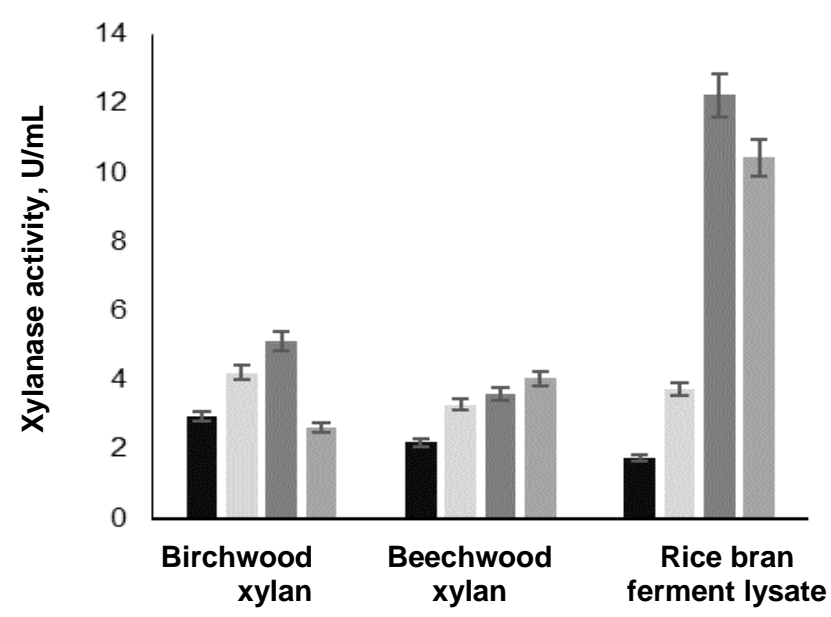

a

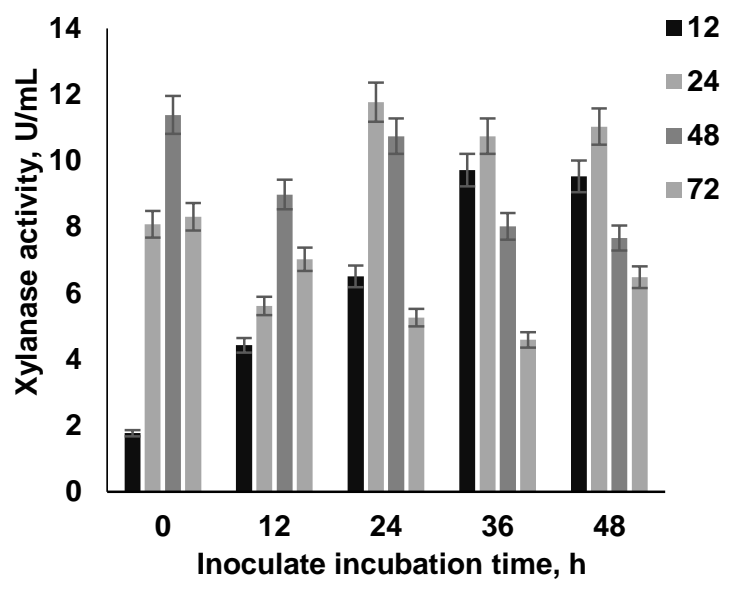

b

Fig. 3. Effect of xylan source (a) and incubation time (b) on xylanase activity (U/mL) in $P$. mucilaginosus strain 560

Рис. 3. Влияние источника ксилана (a) и продолжительности инкубации инокулята (b) на ксиланазную активность (ед./Мл) штамма 560 бактерий $P$. mucilaginosus

tionin bacteria P. mucilaginosus strain 560 (Fig. 3, a). This observation may relate to the presence of specific inductors produced in the partial hydrolysis of ferment lysate, which boost the xylanase biosynthesis as reported by [33] in experiments examining fungal xylanase production in Aspergillus and Trichoderma. As shown in [34], specific inductor substances play a key role in xylanase biosynthesis regulation. Among those are xylose, xylobiose, xylooligosaccharides, xylose heterodisaccharides and their positional isomers formed during the enzymatic hydrolysis of rice bran fibre. Inoculate incubation time under the trial conditions was found to have an insignificant effect on bacterial growth and xylanase production (Fig. 3, b; see Table 2). Accordingly, the inoculum pretreatment is not required for experimental assays.
Effect of nitrogen source and concentration. Trials with various nitrogen sources demonstrated a maximal xylanase activity after a $48 \mathrm{~h}$ cultivation with carbamide supplemented medium (Fig. 4, a). A carbamide content of $0.2 \%$ increased the xylanase activity by 2-4 times compared to the control (no nitrogen) (Fig. 4, b). Under optimal cultivation conditions, the maximum xylanase activity in the stationary phase reached $20 \mathrm{U} / \mathrm{mL}$, giving a 2-fold increase compared to $P$. campinasensis BL11 cultured under optimal conditions on a lye-treated rice bran-straw lysate medium (xylanase $10.5 \mathrm{U} / \mathrm{mL}$ ) [35].

A combined application of ammonium sulphate and yeast extract in the medium increased the P. mucilaginosus biomass yield (see Table 2). 


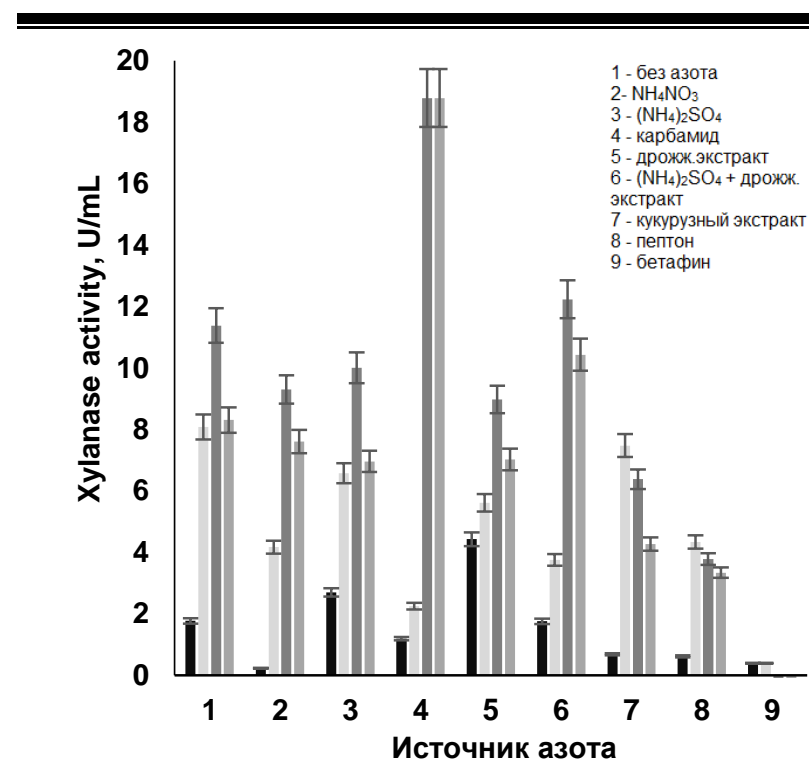

a

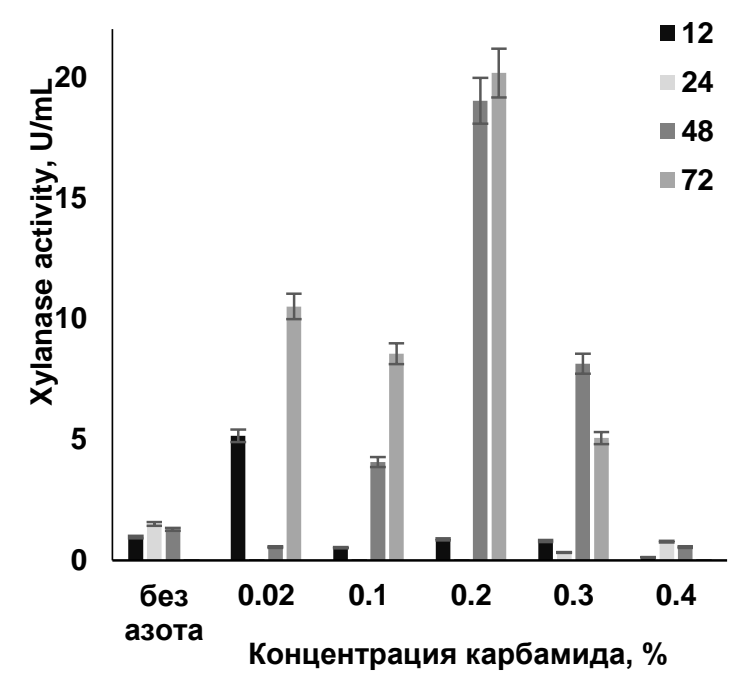

$\mathrm{b}$

Fig. 4. Effect of nitrogen source (a) and concentration (b) in medium on xylanase activity $(\mathrm{U} / \mathrm{mL})$ in $P$. mucilaginosus strain 560

Рис. 4. Влияние источника азота на ксиланазную активность (ед./мл) штамма 560 бактерий $P$. mucilaginosus: a - источник азота; b - концентрация источника азота в питательной среде

\section{CONCLUSIONS}

We identify the rice bran ferment lysate-based nutrient medium as optimal for the xylanase production in $P$. mucilaginosus strain 560. Calcium supplementation positively affects bacterial growth and xylanase biosynthesis. Recommended cultivation conditions are: carbon source concentration in the medium of $0.5 \%$ of total RS content; $0.2 \%$ carbamide as the optimal nitrogen source; calcium hydroxide as medium $\mathrm{pH}$ corrector to $6.0 \pm 0.2$; cultivation temperature $30 \pm 1{ }^{\circ} \mathrm{C}$. These conditions do not require inoculate pre-treatment of $P$. mucilaginosus strain 560, and a maximal xylanase activity reaches $20 \mathrm{U} / \mathrm{mL}$ in stationary culture.

\section{REFERENCES}

1. Collins T, Gerday C, Feller G. Xylanases, xylanase families and extremophilic xylanases. FEMS Microbiology Reviews. 2005;29(1):3-23. https://doi.org/10.1016/j.femsre.2004.06.005

2. Sedlmeyer FB. Xylan as a by-product of biorefineries: characteristics and potential use for food applications. Food Hydrocolloids. 2014;25(8):18911898. https://doi.org/10.1016/J.FOODHYD.2011.04. 005

3. Shanthi V, Roymon MG. Isolation and screening of alkaline thermostable xylanase producing bacteria from soil in Bhilai Durg region of Chhattisgarh, India. International Journal of Current Microbiology and Applied Sciences. 2014;3(8):303-311.

4. Habibi $Y$, Vignon MR. Isolation and characterrization of xylans from seed pericarp of Argania spinosa fruit. Carbohydrate Research. 2005;340(7):14 31-1436. https://doi.org/10.1016/j.carres.2005.01. 039

5. Singh S, Madlala AM, Prior BA. Thermomyces lanuginosus: properties of strains and their hemicellulases. FEMS Microbiology Reviews. 2003;27 (1):3-16. https://doi.org/10.1016/S0168-6445(03) 00018-4

6. Kulkarni N, Shendye A, Rao M. Molecular and biotechnological aspects of xylanases. FEMS Mi- crobiology reviews. 1999;23(4):411-456. https://doi. org/10.1111/j.1574-6976.1999.tb00407.x

7. Fengel D, Wegener G. Wood: Chemistry. Ultrastructure. Reactions. Berlin. Walter de Gruyter, 1984 (Russ ed.: Fengel D, Vegener G. Drevesina. Khimiya. Ul'trastruktura. Reaktsii. Moscow: Lesnaya promyshlennost': 1988. 511 p.)

8. Chanda SK, Hirst EL, Jones JKN, Percival EGV. 262. The constitution of xylan from esparto grass (Stipa tenacissima, L.). Journal of the Chemical Society (Resumed). 1950:1289-1297. https:// doi.org/10.1039/JR9500001289

9. Eda S, Ohnishi A, Katō K. Xylan isolated from the stalk of Nicotiana tabacum. Agricultural and Biological Chemistry. 1976;40(2):359-364.

10. Barry VC, Dillon T. Occurrence of xylans in marine algae. Nature. 1940;146(3706):620-620. https://doi.org/10.1038/146620a0

11. Percival EGV, Chanda SK. The xylan of Rhodymenia palmate. Nature. 1950;166(4227):787788. https://doi.org/10.1038/166787b0

12. Kaur A, Singh A, Patra AK, Mahajan R. Costeffective scouring of flax fibers using cellulase-free xylano-pectinolytic synergism from a bacterial isolate. Journal of Cleaner Production. 2016;131:107-111. https://doi.org/10.1016/j.jclepro.2016.05.069 
13. Akin DE. Plant cell wall aromatics: influence on degradation of biomass. Biofuels, Bioproducts and Biorefining. 2008;2:288-303. https://doi.org/10. 1002/bbb.76

14. Kaur A, Mahajan R, Singh A, Garg G, Sharma J. A novel and cost effective methodology for qualitative screening of alkalothermophilic cellulase free xylano-pectinolytic microorganisms using agricultural wastes. World Journal of Microbiology and Biotechnology. 2011;27:459-463. https://doi.org/10. 1007/s11274-010-0457-9

15. Subramaniyan S, Prema P. Biotechnology of microbial xylanases: Enzymology, molecular biology and application. Critical Reviews in Biotechnology. 2002;22(1):33-64. https://doi.org/10.1080/0738855 0290789450

16. Velázquez E, de Miguel T, Poza M, Rivas R, Rosselló-Mora R, Villa TG. Paenibacillus favisporus sp. nov., a xylanolytic bacterium isolated from cow faeces. International Journal of Systematic and Evolutionary Microbiology. 2004;54(1):59-64. https//doi. org/10.1099/ijs.0.02709-0

17. Rivas R, Mateos PF, Martínez-Molina E, Velázquez E. Paenibacillus phyllosphaerae sp. nov., a xylanolytic bacterium isolated from the phyllosphere of Phoenix dactylifera. International Journal of Systematic and Evolutionary Microbiology. 2005; 55(2):743-746. https://doi.org/10.1099/ijs.0.63323-0

18. Sánchez MM, Fritze D, Blanco A, Spröer $C$, Tindall BJ, Schumann P, et al. Paenibacillus barcinonensis sp. nov., a xylanase-producing bacterium isolated from a rice field in the Ebro River delta. International Journal of Systematic and Evolutionary Microbiology. 2005;55(2):935-939. https://doi.org/ 10.1099/ijs.0.63383-0

19. Ten LN, Baek SH, Im WT, Lee M, Oh HW, Lee ST. Paenibacillus panacisoli sp. nov., a xylanolytic bacterium isolated from soil in a ginseng field in South Korea. International Journal of Systematic and Evolutionary Microbiology. 2006;56(11):26772681. http://dx.doi.org/10.1099/ijs.0.64405-0

20. Rafikova GF, Loginova EV, Melentev Al, Loginov ON. Biological basis of microbial fodder additive. Patent RF, no. 2662 931, 2018. (In Russian)

21. Li X, Yang SH, Yu XC, Jin ZX, Li WD, Li L, et al. Construction of transgenic Bacillus mucilaginosus strain with improved phytase secretion. Journal of Applied Microbiology. 2005;99(4):878-884. https://doi.org/10.1111/j.1365-2672.2005.02683.x

22. Von Schoultz $S, A B$ BLN-WOODS LTD. Method for extracting biomass. U.S. Patent Application. 14/413,409. 2015. https://doi.org/10.1080/000 31305.1999.10474445

23. Czitrom V. One-factor-at-a-time versus designed experiments. The American Statistician. 1999;53(2):126-131.

24. Maier RM. Environmental microbiology (second edition). Chapter 3. Bacterial growth. Elsevier
Inc. 2009. P. 37-54. https://doi.org/10.1016/B978-012-370519-8.00003-1

25. Bailey M, Biely P, Poutanen K. Interlaboratory testing of methods for assay of xylanase activity. Journal of Biotechnology. 1992;23(3):257-270. https://doi.org/10.1016/0168-1656(92)90074-J

26. Morozova YuA., Skvortsov EV, Alimova FK, Kanarsky AV. Biosynthesis of xylanases and cellulases by fungi Trichoderma on the post-alcohol bard. Vestnik Kazanskogo tekhnologicheskogo universiteta $=$ Bulletin of Kazan Technological University. 2012;15(19):120-122. (In Russian)

27. Dias FE, Okrend H, Dondero NC. Growthpromoting activity of spent sulfite liquor for Sphaerotilus natans growing in a continuous-flow apparatus. Applied Microbiology. 1968;16(2):276-278. https:

//doi.org/10.1128/aem.16.2.276-278.1968

28. Patrauchan MA, Sarkisova S, Sauer K, Franklin MJ. Calcium influences cellular and extracellular product formation during biofilm-associated growth of a marine Pseudoalteromonas sp. Microbiology. 2005;151(9):2885-2897. https://doi.org/10. 1099/mic.0.28041-0

29. Lamed R, Setiter E, Bayer EA. Characterization of a cellulose-binding, cellulase-containing complex in Clostridium thermocellum. Journal of Bacteriology. 1983;156(2):828-836. https://doi.org/ 10.1128/JB.156.2.828-836.1983

30. Grepinet O, Chebrou MC, Beguin P. Nucleotide sequence and deletion analysis of the xylanase gene (xynZ) of Clostridium thermocellum. Journal of Bacteriology. 1988;170(10):4582-4588. https://doi. org/10.1128/jb.170.10.4582-4588.1988

31. Ratanakhanokchai K, Kyu KL, Tanticharoen $M$. Purification and properties of a xylan-binding endoxylanase from alkaliphilic Bacillus sp. strain K-1. Applied and Environmental Microbiology. 1999; 65(2):694-697. https://doi.org/10.1128/AEM.65.2.69 4-697.1999

32. Howieson JG, Robson AD, Abbott LK. Calcium modifies $\mathrm{pH}$ effects on acid-tolerant and acidsensitive strains of Rhizobium meliloti. Australian Journal of Agricultural Research. 1992;43(3):765772. https://doi.org/10.1071/AR9920765

33. Haltrich D, Nidetzky B, Kulbe KD, Steiner W, Župančič $S$. Production of fungal xylanases. Bioresource Technology. 1996;58(2):137-161. https://doi. org/10.1016/S0960-8524(96)00094-6

34. Kulkarni N, Shendye A, Rao M. Molecular and biotechnological aspects of xylanases. FEMS Microbiology Reviews. 1999;23(4):411-456. https: //doi.org/10.1111/j.1574-6976.1999.tb00407.x

35. Ko C-H, Lin Z-P, Tu J, Tsai C-H, Liu C-C, Chen $\mathrm{H}-\mathrm{T}$, et al. Xylanase production by Paenibacillus campinasensis $B L 11$ and its pretreatment of hardwood kraft pulp bleaching. International Biodeterioration \& Biodegradation. 2010;64(1):13-19. https://doi.org/10.1016/j.ibiod.2009.10.001 


\section{БИБЛИОГРАФИЧЕСКИЙ СПИСОК}

1. Collins T., Gerday C., Feller G. Xylanases, xylanase families and extremophilic xylanases // FEMS Microbiology Reviews. 2005. Vol. 29. Issue 1. P. 3-23. https://doi.org/10.1016/j.femsre.2004.06. 005

2. Sedlmeyer F.B. Xylan as a by-product of biorefineries: characteristics and potential use for food applications // Food Hydrocolloids. 2014. Vol. 25. Issue 8. P. 1891-1898. https://doi.org/10.1016/J. FOODHYD.2011.04.005

3. Shanthi V., Roymon M.G. Isolation and screening of alkaline thermostable xylanase producing bacteria from soil in Bhilai Durg region of Chhattisgarh, India // International Journal of Current Microbiology and Applied Sciences. 2014. Vol. 3. Issue 8. P. 303-311.

4. Habibi Y., Vignon M.R. Isolation and characterization of xylans from seed pericarp of Argania spinosa fruit // Carbohydrate Research. 2005. Vol. 340. Issue 7. P. 1431-1436. https://doi.org/10.1016/ j.carres.2005.01.039

5. Singh S., Madlala A.M., Prior B.A. Thermomyces lanuginosus: properties of strains and their hemicellulases // FEMS Microbiology Reviews. 2003. Vol. 27. Issue 1. P. 3-16. https://doi.org/10. 1016/S0168-6445(03)00018-4

6. Kulkarni N., Shendye A., Rao M. Molecular and biotechnological aspects of xylanases // FEMS Microbiology reviews. 1999. Vol. 23. Issue 4. P. 411-456. https://doi.org/10.1111/j.1574-6976.1999. tb00407.x

7. Фенгел Д., Вегенер Г. Древесина. Химия. Ультраструктура. Реакции / пер. с англ. А.В. Оболенской, З.П. Ельницкой; под ред. А.А. Леоновича. М.: Лесная промышленность, 1988. $511 \mathrm{c}$.

8. Chanda S.K., Hirst E.L., Jones J.K.N., Percival E.G.V. 262. The constitution of xylan from esparto grass (Stipa tenacissima, L.) // Journal of the Chemical Society (Resumed). 1950. P. 1289-1297. https://doi.org/10.1039/JR9500001289

9. Eda S., Ohnishi A., Katō K. Xylan isolated from the stalk of Nicotiana tabacum // Agricultural and Biological Chemistry. 1976. Vol. 40. Issue 2. P. 359-364.

10. Barry V.C., Dillon T. Occurrence of xylans in marine algae // Nature. 1940. Vol. 146. Issue 3706. P. 620-620. https://doi.org/10.1038/146620a0

11. Percival E.G.V., Chanda S.K. The xylan of Rhodymenia palmate // Nature. 1950. Vol. 166. Issue 4227. P. 787-788. https://doi.org/10.1038/1667 $87 \mathrm{~b} 0$

12. Kaur A., Singh A., Patra A.K., Mahajan R. Cost-effective scouring of flax fibers using cellulasefree xylano-pectinolytic synergism from a bacterial isolate // Journal of Cleaner Production. 2016. Vol. 131. P. 107-111. https://doi.org/10.1016/j.jclepro.20 16.05.069

13. Akin D.E. Plant cell wall aromatics: influence on degradation of biomass // Biofuels, Bioproducts and Biorefining. 2008. Vol. 2. P. 288-303. https: //doi.org/10.1002/bbb.76

14. Kaur A., Mahajan R., Singh A., Garg G., Sharma J. A novel and cost effective methodology for qualitative screening of alkalothermophilic cellulase free xylano-pectinolytic microorganisms using agricultural wastes // World Journal of Microbiology and Biotechnology. 2011. Vol. 27. P. 459-463. https://doi.org/10.1007/s11274-010-0457-9

15. Subramaniyan S., Prema P. Biotechnology of microbial xylanases: Enzymology, molecular biology and application // Critical Reviews in Biotechnology. 2002. Vol. 22. Issue 1. P. 33-64. https://doi. org/10.1080/07388550290789450

16. Velázquez E., de Miguel T., Poza M., Rivas R., Rosselló-Mora R., Villa T.G. Paenibacillus favisporus sp. nov., a xylanolytic bacterium isolated from cow faeces // International Journal of Systematic and Evolutionary Microbiology. 2004. Vol. 54. Issue 1. P. 59-64. https//doi.org/10.1099/ijs.0.027 09-0

17. Rivas R., Mateos P.F., Martínez-Molina E., Velázquez E. Paenibacillus phyllosphaerae sp. nov., a xylanolytic bacterium isolated from the phyllosphere of Phoenix dactylifera // International Journal of Systematic and Evolutionary Microbiology. 2005. Vol. 55. Issue 2. P. 743-746. https://doi.org/10.10 99/ijs.0.63323-0

18. Sánchez M.M., Fritze D., Blanco A., Spröer C., Tindall B.J., Schumann P., et al. Paenibacillus barcinonensis sp. nov., a xylanase-producing bacterium isolated from a rice field in the Ebro River delta // International Journal of Systematic and Evolutionary Microbiology. 2005. Vol. 55. Issue 2. P. 935939. https://doi.org/10.1099/ijs.0.63383-0

19. Ten L.N., Baek S.H., Im W.T., Lee M., Oh H.W., Lee S.T. Paenibacillus panacisoli sp. nov., a xylanolytic bacterium isolated from soil in a ginseng field in South Korea // International Journal of Systematic and Evolutionary Microbiology. 2006. Vol. 56. Issue 11. P. 2677-2681. http://doi.org/10.1099/ ijs.0.64405-0

20. Пат. № 2662931, Российская Федерация, C12N 1/20, C12N 9/00. Биологическая основа микробной кормовой добавки / Г.Ф. Рафрикова, Логинова Е.В., Мелентьева А.И., Логинов О.Н.; заявл.22.02.2017; опубл. 31.07.2018.

21. Li X., Yang S.H., Yu X.C., Jin Z.X., Li W.D., Li L., et al. Construction of transgenic Bacillus mucilaginosus strain with improved phytase secretion // Journal of Applied Microbiology. 2005. Vol. 99. Issue 4. P. 878-884. https://doi.org/10.1111/j.13652672.2005.02683.x

22. Von Schoultz S., AB BLN-WOODS LTD. Method for extracting biomass. U.S. Patent Application. 14/413,409. 2015. https://doi.org/10.1080/0003 1305.1999.10474445

23. Czitrom V. One-factor-at-a-time versus de- 
signed experiments // The American Statistician. 1999. Vol. 53. Issue 2. P. 126-131.

24. Maier R.M. Environmental microbiology (second edition). Chapter 3. Bacterial Growth. Elsevier Inc. 2009. P. 37-54. https://doi.org/10.1016/B97 8-0-12-370519-8.00003-1

25. Bailey M., Biely P., Poutanen K. Interlaboratory testing of methods for assay of xylanase activity // Journal of Biotechnology. 1992. Vol. 23. Issue 3. P. 257-270. https://doi.org/10.1016/0168-1656(92) 90074-J

26. Морозова Ю.А., Скворцов Е.В., Алимова Ф.К., Канарский А.В. Биосинтез ксиланаз и целлюлаз грибами рода Trichoderma на послеспиртовой барде // Вестник Казанского технологического университета. 2012. Vol. 15. N 19. P. 120- 122.

27. Dias F.E, Okrend H., Dondero N.C. Growthpromoting activity of spent sulfite liquor for Sphaerotilus natans growing in a continuous-flow apparatus // Applied Microbiology. 1968. Vol. 16. Issue 2. P. 276-278. https://doi.org/10.1128/aem.16.2.276-278. 1968

28. Patrauchan M.A., Sarkisova S., Sauer K., Franklin M.J. Calcium influences cellular and extracellular product formation during biofilm-associated growth of a marine Pseudoalteromonas sp. // Microbiology. 2005. Vol. 151. Issue 9. P. 2885-2897. https://doi.org/10.1099/mic.0.28041-0

29. Lamed R., Setiter E., Bayer E.A. Characterization of a cellulose-binding, cellulase-containing complex in Clostridium thermocellum // Journal of Bacteriology. 1983. Vol. 156. Issue 2. P. 828-836. https://doi.org/10.1128/JB.156.2.828-836.1983

30. Grepinet O., Chebrou M.C., Beguin P. Nu-

\section{Contribution}

Dung T. Ha, Albert V. Kanarsky, Zosia A. Kanarskaya, Andrei V. Shcherbakov, Elena N. Shcherbakova, Andrey V. Pranovich carried out the experimental work, on the basis of the results summarized the material and wrote the manuscript. All authors have equal author's rights and bear equal responsibility for plagiarism.

\section{Conflict interests}

The authors declare no conflict of interests regarding the publication of this article.

The final manuscript has been read and approved by all the co-authors.

\section{INFORMATION ABOUT THE AUTHORS}

\section{Dung T. Ha,}

Postgraduate Student,

Department of Food Biotechnology,

Kazan National Research Technological

University, cleotide sequence and deletion analysis of the xylanase gene (xynZ) of Clostridium thermocellum // Journal of Bacteriology. 1988. Vol. 170. Issue 10. P. 4582-4588. https://doi.org/10.1128/jb.170.10.45824588.1988

31. Ratanakhanokchai K., Kyu K.L., Tanticharoen M. Purification and properties of a xylanbinding endoxylanase from alkaliphilic Bacillus $s p$. strain K-1 // Applied and Environmental Microbiology. 1999. Vol. 65. Issue 2. P. 694-697. https://doi. org/10.1128/AEM.65.2.694-697.1999

32. Howieson J.G., Robson A.D., Abbott L.K. Calcium modifies $\mathrm{pH}$ effects on acid-tolerant and acidsensitive strains of Rhizobium meliloti // Australian Journal of Agricultural Research. 1992. Vol. 43. Issue 3. P. 765-772. https://doi.org/10.1071/AR99 20765

33. Haltrich D., Nidetzky B., Kulbe K.D., Steiner W., Župančič S. Production of fungal xylanases // Bioresource Technology. 1996. Vol. 58. Issue 2. P. 137-161. https://doi.org/10.1016/S0960-8524(96) 00094-6

34. Kulkarni N., Shendye A., Rao M. Molecular and biotechnological aspects of xylanases // FEMS Microbiology Reviews. 1999. Vol. 23. Issue 4. P. 411-456. https://doi.org/10.1111/j.1574-6976.1999. tb00407.x

35. Ko C.-H., Lin Z.-P., Tu J., Tsai C.-H., Liu C.-C., Chen H.-T., et al. Xylanase production by Paenibacillus campinasensis BL11 and its pretreatment of hardwood kraft pulp bleaching // International Biodeterioration \& Biodegradation. 2010. Vol. 64. Issue 1. P. 1319. https://doi.org/10.1016/j.ibiod.2009.10.001

\section{Kрuтерuи авторства}

Ха Т.З., Канарский А.В., Канарская 3.А., Щербаков А.В., Щербакова Е.Н., Пранович А.В. выполнили экспериментальную работу, на основании полученных результатов провели обобщение и написали рукопись. Авторы имеют на статью равные авторские права и несут равную ответственность за плагиат.

\section{Конфликт интересов}

Авторы заявляют об отсутствии конфрликта интересов.

Все авторы прочитали и одобрили окончательный вариант рукописи.

\section{СВЕДЕНИЯ ОБ АВТОРАХ}

Ха Тхи Зунг,

аспирант кафедры пищевой биотехнологии, Казанский национальный исследовательский технологический университет,

420015 , г. Казань, ул. Толстова, 8 , 
8, Tolstov St., Kazan, 420015,

Russian Federation,

e-mail: coldwind.91@mail.ru

Albert V. Kanarsky,

Dr. Sci. (Engineering), Professor, Department of Food Biotechnology,

Kazan National Research Technological

University,

8, Tolstov St., Kazan, 420015,

Russian Federation,

凶e-mail:alb46@mail.ru

\section{Zosia A. Kanarskaya,}

Cand. Sci. (Engineering), Associate Professor

Department of Food Biotechnology,

Kazan National Research Technological

University,

8, Tolstov St., Kazan, 420015,

Russian Federation,

e-mail: zosya_kanarskaya@mail.ru

Andrei V. Shcherbakov,

Cand. Sci. (Biology), Researcher,

Laboratory of Microbial Technology,

All-Russia Research Institute for Agricultural

Microbiology,

3, Podbelsky Highway, St. Petersburg, 196608,

Russian Federation,

e-mail: microbe-club@inbox.ru

\section{Elena N. Shcherbakova,}

Cand. Sci. (Agriculture), Researcher, Laboratory of Microbial Technology,

All-Russia Research Institute for Agricultural Microbiology,

3, Podbelsky Highway, St. Petersburg, 196608, e-mail: alonagonchar@mail.ru

\section{Andrey V. Pranovich,}

Cand. Sci. (Chemistry), Associate Professor, Department of Wood Chemistry,

Laboratory of Wood and Paper Chemistry,

Abo Academy,

3, Tuomiokirkontori, Turku/Abo, FI-20500,

Finland,

e-mail: apranovi@abo.fi
Российская Федерация, e-mail: coldwind.91@mail.ru

Канарский Альберт Владимирович, д.Т.Н., профрессор кафедры пищевой биотехнологии,

Казанский национальный исследовательский технологический университет, 420015 , г. Казань, ул. Толстова, 8 , Российская Федерация, $\bowtie$ e-mail: alb46@mail.ru

\section{Канарская Зося Альбертовна,}

к.Т.н., доцент кафедры пищевой биотехнологии,

Казанский национальный исследовательский технологический университет, 420015, г. Казань, ул. Толстова, 8 , e-mail: zosya_kanarskaya@mail.ru

\section{Щербаков Андрей Владимирович,} к.б.н., научный сотрудник лаборатории технологии микробных препаратов, Всероссийский НИИ сельскохозяйственной метеорологии

196608, С.-Петербург, шоссе Подбельского, 3 , Российская Федерация, e-mail: microbe-club@inbox.ru

\section{Щербакова Елена Николаевна,}

к.С-Х.н., младший научный сотрудник лаборатории технологии микробных препаратов,

Всероссийский НИИ сельскохозяйственной метеорологии, 196608, С.-Петербург, шоссе Подбельского, 3, Российская Федерация, e-mail: alonagonchar@mail.ru

\section{Пранович Андрей Викторович,}

к.Х.н., доцент кафедеры химии древесины и бумаги,

Або Академия,

Туомиокирконтори 3, Турку/Або, FI-20500, Финляндия,

e-mail: apranovi@abo.fi 